\title{
sciendo
}

\section{Effects of changes in stock market index composition on stock returns: event study methodology on Zagreb Stock Exchange}

\author{
Tihana Škrinjarić \\ Department of Mathematics, University of Zagreb Faculty of Economics and Business, \\ Croatia \\ tskrinjar@net.efzg.hr
}

\begin{abstract}
This paper observes the short-run effects of stock market index composition changes on stock returns on the Zagreb Stock Exchange (ZSE). In that way, event study methodology is employed in order to estimate abnormal returns and compare them amongst three subsets of stocks: those leaving the market index, those entering it, and constantly included stocks. The research included 14 regular and extraordinary revisions of the market index in the period from January 2nd, 2015 until March 21 st, 2018. The results have confirmed two research hypotheses: stock exclusions from the market index have a negative effect on stock returns on the ZSE, which is consistent with the price pressure hypothesis; and there exist asymmetric effects of index composition changes on stock returns. This is the first study of this kind on the Croatian stock market, thus more questions need to be answered in future research.
\end{abstract}

Keywords: abnormal returns, Croatian stock market, event study, index composition change.

JEL classification: G12, G14.

DOI: 10.2478/crebss-2019-0005

Received: June 25, 2018

Accepted: April 04, 2019

\section{Introduction}

Event study methodology has become very popular in the last 20 years in order to obtain insights into the effects of (un)expected economic, political and other events and announcements on stock returns. It is also a useful tool for evaluating the validity of the (weak form of) Efficient Market Hypothesis (EMH henceforward, see Fama (1965, 1970). Since the EMH states that new information on stocks and firms incorporates very quickly into stock prices, almost instantaneously, there are no possibilities to obtain abnormal profits on the stock market in the long run. This study focuses on the announcements of stock market index structure revisions and their effects on the stock returns on the Zagreb Stock Exchange (ZSE). In that way, insights can be made on the investors' anticipations on the market and possibilities to obtain extraordinary returns. This means that in the short term, stock price changes can be forecasted and anticipated in the correct direction. In that way, portfolio restructuring could be performed in a way that investor could preserve the value of his portfolio in bad 
market times and/or increase the portfolio value when the good market time is anticipated. Since there exist funds, which try to minimize their tracking error regarding market portfolio, the changes in market index composition can affect their stock demand curves in the short and long run. Thus, some information can be obtained on ZSE market participants' stock demand curves.

The purpose of this study is twofold. Firstly, an overview of relevant theoretical and empirical research will be summarized in order to inform (potential) investors on the mentioned topic. The second purpose is to empirically evaluate the effects of market index revision announcements on stock returns on ZSE. This is the first study in Croatia which observes short-run changes in stock demand curves by using event study methodology. The following research hypotheses are tested in the study. The first hypothesis states that stock exclusions from the market index have a negative effect on stock returns on ZSE. The second hypothesis states that there exist asymmetric effects of index composition changes on stock returns. This means that stock inclusions and exclusions in and from the market index do not have the same effect on stock returns. Investors do not perceive inclusions and exclusions of stocks identically, which leads to different rates of increase or decline of stock returns around the announcement date.

Several hypotheses have been developed over the years which try to explain the effects of stock market index structure changes on the stock prices. These hypotheses have been developed by observing the S\&P500 index; however, after the research of Lynch and Mendenhall (1997), this type of study has been extended for other markets as well (Duque, Madeira, 2004). The most prominent hypotheses which have been theoretically and empirically observed in the past three decades are as follows. The price pressure hypothesis (PPH), firstly developed in Scholes (1972) and Kraus and Stoll (1972), states that stocks have a short-term downward sloping demand curve. Thus, demand shocks due to indexing should affect stock prices momentarily, but the shock should disappear when the excess demand is satisfied. Elliott et al. (2006) explain that market frictions create short run constraints on the market, which results in a pricepressure effect. This hypothesis is closely related to index funds which aim to minimize the tracking error, due to changes in index composition which have consequences on the demand and trading activity of those funds. However, PPH does support the $\mathrm{EMH}$ in the long run, because PPH assumes that all of the frictions occur only in short run and no permanent shifts of stock demand curve are made in the long run. The second hypothesis is called imperfect substitutes hypothesis (ISH) or the long-term downward sloping demand hypothesis. Shleifer (1986) explains that demand shocks should be permanently reflected in excess returns if stocks have a long term downward sloping demand curve. This is contrary to the Capital Asset Pricing Model (CAPM), where demand curves for stocks are horizontal due to prices entirely reflecting the market's perceptions of risks and returns. Thus, in a CAPM setting, investors can change their portfolio structure using almost perfect substitutes (Kraus, Stoll 1972). In the ISH setting, stocks are no longer perfect substitutes, because stocks which are added to the index are not viewed as stocks which are not added to the market index. Thus, the long run demand curve is inelastic and downward sloping. More details can be found in Kaul et al. (2000), Blume and Edelen (2002) and Wurgler and Zhuravskaya (2002).

The liquidity hypothesis ( $\mathrm{LH}$, or information cost hypothesis, $\mathrm{ICH}$ ) deals with stocks which enter the market index. Their returns could decline and there are several reasons. Hegde and McDermott (2003) explain that returns of those stocks decline due to their inclusion in the index as they become more liquid. Chen et al. (2004) consider the asymmetry of information as the explanation: the asymmetry declines about 
stocks which enter the market index, which contributes to the increase of their liquidity. It can be said that investors demand an extra premium for holding stocks which are not in the market index due to them having higher transaction costs and having less available information on those stocks. The fourth hypothesis is the increased awareness hypothesis (IAH, or attention awareness hypothesis, AAH), developed in Merton (1987). Here, it is assumed that investors are not aware of all investment possibilities on the stock market. When a stock of which investors were not aware of enters the market index, they get more informed about that stock. Including that stock in their portfolios, leads to decline in stock's return because investors demand a higher return for bearing the idiosyncratic risk. Certification (or information signalling) hypothesis $(\mathrm{CH}, \mathrm{ISH})$ is explained as follows. When a stock enters the market index, investors' expectations about future cash flows of the firm get higher (Dhillon, Johnson, 1991). So, the addition to the market index is considered as good news and deletion as bad news. Jain (1987) states that a firm needs to signal something positive about future prospects after being added to the index.

As can be seen, the explanations are quite diverse by focusing on the short or long run, the liquidity of the stocks on the market, investors' awareness, etc. This research will primarily focus on the short term effects on stock returns in order to examine whether there exist any effects on the stock returns on ZSE. The second section gives an overview of the previous relevant empirical research. Afterward, the third section describes the methodology used in the study. Fourth section deals with empirical results and interpretations. The final, fifth section concludes the research with recommendations for future research.

\section{Previous research}

The literature on effects associated with changes in index structure is extending rapidly, especially in the last couple of years. The majority of first empirical papers to emerge observed the American market. Early work consists of Shleifer (1986), Harris and Gurel (1986), Jain (1987), Lynch and Mendenhall (1997), Erwin and Miller (1998), Hegde and McDermott (2003), Chen et al. (2004), etc. In the last couple of years, studies of European and Asian markets have been emerging as well. The majority of the literature focuses on the short term effects of inclusion/exclusion to/from the market index and utilize the event study methodology. If more data is available, such as liquidity, bid-ask spreads and similar characteristics, regression models are applied as well in order to distinguish the effects for different types of stocks.

Shleifer (1986) examined the effects of entering the S\&P500 index on stock returns in the period 1966-1983 by using event study methodology and regression analysis. Results indicated that around announcement days returns on entering stocks rise and stay high up until 10 days after the announcement day. The liquidity of those stocks rises as well, and the author concludes that in the short run, the demand curve for stocks is downward sloping. Harris and Gurel (1986) observed price and volume reactions regarding announcements on restructuring S\&P500 (period 1973-1983). Authors concluded that PPH stands, due to a large increase in volume and price on the first trading day after an addition to the index. However, the effects are reversed after two weeks, which supports the short-run validity of the hypothesis. Jain (1987) also observed the S\&P 500 index and its stocks (for the period 1977-1983) by employing the event study methodology. The author observed both the short and long run and determined that stocks added to the market index experienced an excess return of $+4 \%$ on the first trading day after the announcement, whilst stocks exiting the index experienced loss of 1\%. Jain (1987) explained the results that the S\&P prefers stable firms which have reduced the riskiness of its stocks. Lynch and Mendenhall (1996) 
provided an analysis of S\&P stocks for the period 1989-1995 via event study methodology. They simultaneously test for four hypotheses (above mentioned in the introduction, with the exception of the $\mathrm{CH}$. The study was very extensive, including price and volume trading data. Main findings include a significantly positive effect on the announcement day for stock additions (with an abnormal return of $+3.8 \%$ ) and negative for exclusions. This was one of the first studies to observe stocks which exit the market index alongside entering stocks. Erwin and Miller (1998) observed the S\&P500 stocks for the period 1984-1988 and examined changes in stock liquidity measured by the bid-ask spread. The bid-ask spread decreases for stock additions to the market index, as accordance with the liquidity hypothesis.

Some of the research not focusing only on the American stock market is the following. Mase (2007) states it was the first study to carry out both short and long term testing. The author observed the FTSE 100 index stocks in the period from 1992 to 1999. In the study, a buy and hold strategy for the long run was conducted. Results showed that deletions from the market index lead to abnormal losses (more than $16 \%$ loss) in three years, while the additions lead up to more than $+17 \%$ abnormal returns. Moreover, the author confirmed significant short term cumulative abnormal returns as well for stock additions. Bechman (2004) focused on the Danish market (KFX index, period 1989-2001). The author found that deleted stocks suffer from abnormal returns of $-16 \%$ six months after the announcement day, as well as a decrease in trading volume. On the other hand, stocks which have entered the market index resulted with 5\% abnormal returns, which the author justifies with the ISH and the LH hypotheses. Gregoriou and loannidis (2006) observed the FTSE 100 index over the period 1984-2001. The difference of this study compared to Mase (2007) is that research from 2006 observed short term effects of index inclusion. Gregoriou and loannidis (2006) find evidence in favour of LH because of prices and trading volumes of firms which enter the market index increase. The opposite was found to be true for stocks leaving the FTSE index. Vespro (2006) explored effects index composition changes of the French market (CAC40 and SBF120) along with the UK market (FTSE100) for the period 19972001. Results support evidence of PPH and no evidence in favour of other hypotheses (mentioned earlier): share prices overreact to non-information, but the result is short lived. Gregoriou (2011) also observed the CAC40 index (with almost the same time sample size as Vespro (2006), from 1997-2001). The results are a bit different compared to Vespro (2006), due to observing the bid-ask spread as the main focus of measuring liquidity. Gregoriou (2011) finds improvements in liquidity of stocks due to addition to the market index. The study concludes that investors on the French market demand a larger risk premium for investing in those stocks on which they have less available information. Oberndorfer et al. (2013) focused on the German stocks which constitute DJSI STOXX index (sustainability index) between 1999 and 2002. Authors also observed the short run, as the majority of previously mentioned research. Findings suggest that investors penalize the inclusion into the market index (abnormal returns are losses of $2 \%$ five days after the event date). In other words, results show that higher corporate environmental or social performance (inclusion in the DJSI) is not financially rewarded on the market. They try to reason such results as a symbolic action. Namely, such reaction of investors is actually a reaction to institutional pressures which require firms to do certain changes regarding business sustainability which leads to additional unproductive costs. A detailed discussion on other relevant literature on this topic is given in Duque and Madeira (2004).

Work in Croatia is, unfortunately limited. Only two papers, which can be considered, connected to this area are Miletić (2011) and Škrinjarić and Orlović (2019). Miletić (2011) used event study methodology in order to observe the effects of dividend 
announcements on stock prices on Zagreb Stock Exchange in the period 2007 - end of 2009. The stocks sample was divided into three subsets: first one consisted of firms which announcement increase of dividends, second of those who announced a decrease of dividends and the third group included those with no change in dividends. The results showed that there exists a positive significant effect of increase dividend announcements on price changes on the Croatian market. Škrinjarić and Orlović (2019) focused on the political events regarding the concern Agrokor at the beginning of 2017. Authors utilized the event study methodology by dividing stocks on Zagreb stock exchange into two groups: the first group of stocks consisted of those, which belong to companies within the Agrokor concern and the other group of other liquid stocks. Results indicated that selected events regarding the Agrokor crisis have affected the first group of stocks (Agrokor ones) suffered from lowering returns in the spring of 2017, whilst other stocks were not affected significantly. Other studies of the effects of announcements and political and economic events effects on stock returns do not exist. Thus, a lot of unanswered questions remain to be explored.

\section{Research methodology}

Event study methodology consists of several steps. Here, we follow MacKinlay (1997) and Kothari and Warner (2007) in describing the main elements of this methodology. Actual returns of $i$-th stock at date tare denoted with $r_{i, t}$ and abnormal returns of $i$-th stock at date t with $A R_{i, t}$, which are calculated as:

$$
A R_{i, t}=r_{i, t}-E\left(r_{i, t} \mid \Omega_{t}\right) \text {, }
$$

where $E\left(r_{i, t} \mid \Omega_{+}\right)$is the conditional return of $i$-th stock at date t based upon information matrix $\Omega$ t. Usually, the conditional return is calculated as an average return over a time period:

or estimated via market model:

$$
E\left(r_{i, t} \mid \Omega_{t}\right)=\frac{1}{T} \sum_{t=1}^{T} r_{i, t}
$$

$$
E\left(r_{i, t} \mid \Omega_{t}\right)=E\left[a_{i}+\beta r_{M, t}+\varepsilon_{i, t}\right],
$$

where $r_{M, t}$ denotes stock market index return at date $t$ and $\varepsilon_{i, t}$ is the error term of $i$-th stock at date $t, \varepsilon_{i} \sim N\left(0, \sigma_{i}^{2}\right)$. Relation (2) or (3) is estimated in the so-called pre-event window and (1) is calculated in the event window. Lengths of the pre-event $(T)$ and event window (T') vary in literature and depend upon the observed events and data availability. However, short length event window tests have high power and low sensitivity of the test statistic specification to assumptions about the expected returns, but there exists high sensitivity of test to the sample size of stocks included (see Kothari and Warner 2007 for a detailed discussion). Since this research deals with a specific question on the inclusion or exclusion of stocks in the market index, the sample size of each group is limited. One research which deals with small sample sizes in event studies is Bartholdy et al. (2007). Authors find that small samples could result with profound results and they advise to use non-parametric tests if possible, especially when using thinly traded stocks.

The main hypothesis which is tested is whether the observed event has significantly affected stock returns. A test can be conducted by observing average abnormal return in the event window $\overline{A R}_{\tau}, \tau \in \tau_{\text {start }}, \ldots, \tau_{\text {event }}, \ldots, T^{\prime}$, calculated as

with its variance

$$
\overline{A R}_{\tau}=\frac{1}{I} \sum_{i=1}^{I} A R_{i, \tau}
$$

$$
\operatorname{var}\left(\overline{A R}_{\tau}\right)=\frac{1}{I^{2}} \sum_{i=1}^{I} \sigma_{\varepsilon_{i}}^{2}
$$

and calculating the test value 


$$
\frac{\overline{A R}_{\tau}}{\operatorname{var}\left(\overline{A R}_{\tau}\right)}
$$

which asymptotically (with respect to the number of stocks I) follows a standardized normal distribution with zero value of expected value under the null hypothesis. MacKinlay (1997) states that it is necessary to aggregate in order to provide useful test results. This is why abnormal returns are aggregated across stocks by calculating cumulative abnormal returns $\overline{C A R}_{\tau}$ as

with variance

$$
\overline{C A R}_{\tau}=\sum_{\tau=\tau_{\text {start }}}^{\tau} \overline{A R}_{\tau}
$$

$$
\operatorname{var}\left(\overline{C A R}_{\tau}\right)=\frac{1}{I^{2}} \sum_{i=1}^{I} \operatorname{var}\left(\overline{A R}_{\tau}\right) .
$$

for every day in the event window. Now, the null hypothesis can be tested using value

$$
\theta_{1} \frac{\overline{C A R}_{\tau}}{\operatorname{var}\left(\overline{C A R}_{\tau}\right)} \sim N(0,1) \text {. }
$$

When dealing with a smaller number of stocks, non-parametric tests are advised to be used, such as the sign test. Sign test requires that (cumulative) abnormal returns are independent across stocks. Thus, the null hypothesis assumes that: $p \leq 0$, where $p$ denotes the number of stocks with $P\left(C A R_{i}\right) \geq 0$ (i.e. proportion of positive abnormal returns). Test statistic is then given as:

$$
\theta_{2}=\left(\frac{I^{+}}{I}-0.5\right) \frac{\sqrt{I}}{0.5} \sim N(0,1),
$$

where the number of stocks with $P\left(C A R_{i}\right) \geq 0$ is denoted with $1^{+}$. More details on event study methodology can be seen in Corrado (2010).

\section{Empirical results and discussion}

Daily data on stock prices of stocks which constitute market index CROBEX and value of the market index was collected from Zagreb Stock Exchange (2018). The observed period is January 2nd, 2015 until March $21^{\text {st }}, 2018$. Each stock and market index return was calculated as a continuous return. Next, news announcements of ZSE on regular and extraordinary revisions of the structure of CROBEX have been collected from ZSE (2018) as well. In the observed period, there were in total 14 regular and extraordinary changes in the CROBEX index structure. Dates of the announcement days of the change with the number of stocks in the index are shown in Table 1.

Table 1 Dates of extraordinary and regular changes of CROBEX structure

\begin{tabular}{|r|c|}
\hline Announcement day & Number of stocks \\
\hline January $19^{\text {th }} 2015$ & 24 \\
March $6^{\text {th }} 2015$ & 29 \\
July $31^{\text {st }} 2015$ & 18 \\
September $4^{\text {th }} 2015$ & 24 \\
October $27^{\text {th }} 2015$ & 21 \\
January 20th 2016 & 19 \\
March $3^{\text {rd }} 2016$ & 25 \\
September $8^{\text {th }} 2016$ & 25 \\
November $8^{\text {th }} 2016$ & 20 \\
March $6^{\text {th }} 2017$ & 26 \\
May $8^{\text {th }} 2017$ & 18 \\
June $9^{\text {th }} 2017$ & 18 \\
September $8^{\text {th }} 2017$ & 17 \\
March $7^{\text {th }} 2018$ & 17 \\
\hline
\end{tabular}

Source: author based upon ZSE (2018) announcements. 
The number of stocks varies over time, with a total of 32 stocks, which entered the market index, 279 stocks, which were constantly in the index (i.e. stocks are being repeatedly in the structure; however, for formal testing, stocks have to be observed as different entities which results with 279 "different" entities), and 32 stocks, which have left the market index. Some of the stocks have re-entered the market index return. In that way, the subsamples have repeating stocks in them for different time periods. The three subsamples of stocks will be denoted as follows: the first subsample is called "leaving", second "no change" and third "entering" stocks.

For the pre-event window, a length of 59 days was chosen for the estimation of the model (3). Although MacKinlay (1997) recommends using 120 days for the pre-event window length, we had to take into account that a minimum of 10 days has passed after the change of CROBEX structure, which was before the date January $19^{\text {th }}, 2015$, as the first announcement date in the research. Shorter pre-event window is based upon excluding the previous rebalancing of the CROBEX structure, so that the initial model does not include the effects from the previous rebalancing. MacKinlay (1997) recommends the mentioned 120 days mostly for mergers and acquisitions; thus the length of the pre-event window varies in the literature. Based on the estimates of the model (3), forecasts were made for each stock in the observed event periods. These forecasts $E\left(r_{i, t} \mid \Omega_{t}\right)$, were subtracted from the actual values of returns ri,t in order to calculate abnormal returns. A length of 21 days was chosen for the event window, in order to observe the results of testing the hypothesis "announcements on changing the structure of CROBEX does not affect return series significantly": 10 days prior the announcement day (event day) and 10 days after. In that way, short-term changes will be observed as an initial point to explore if any effects exist on ZSE.

The results are shown for all three groups of stocks in Table 2. It can be seen that the null hypothesis cannot be rejected in the case of all three subsamples of stocks when using test value in (9). Although, the test value is negative for the leaving stocks subsample for the entire event window, which means that average value of return series was negative in each day (this is confirmed by observing the cumulative abnormal return in the third column of each subgroup). This is in accordance with the price pressure hypothesis. In the short run, which is observed in this study, the demand curve of stocks on ZSE could be downward sloping. The test value is negative for entering stocks before the announcement day and positive after the event day. This could be in line with the liquidity hypothesis. Since stocks which enter the CROBEX index are those which are most liquid (one of the rules for entering the index on ZSE), their transaction costs get lower and those stocks become less expensive.

By observing the results of the non-parametric test and test value in (10), we obtain significant results for every day for leaving stocks. The test values are statistically significant and negative. Valve gets lower as we approach the event day, meaning that some information on stocks leaving the market index is leaking towards the investors. The test value also rejects the null hypothesis after the event day, which means that announcements on leaving the market index are perceived negatively amongst investors, who then try to sell those stocks and making lowering price pressures. In that way, the first research hypothesis is confirmed.

There are no effects on stocks which do not enter nor leave the market index by observing the results of the second test as well. Thus, it can be concluded that announcements of other stocks leaving or entering the market index do not affect the second group of stocks on the Zagreb Stock Exchange. The entering stocks group has some significant values of the test value (10) which confirms the aforementioned liquidity hypothesis. Columns denoted with indicate the value of the average cumulative abnormal return of every subsample of stocks. On the announcement 
day, the leaving stock group has a cumulative loss of $4.63 \%$, which is much lower compared to the other two groups. The result is consistent with previous studies and even gets worse as the post event days go further to the end of the +10 day window.

Table 2 Results of testing the hypothesis of no effects of announcement news on stock returns

\begin{tabular}{|c|c|c|c|c|c|c|c|c|c|}
\hline \multirow{2}{*}{ Day } & \multicolumn{3}{|c|}{ Leaving stocks } & \multicolumn{3}{|c|}{ No change stocks } & \multicolumn{3}{|c|}{ Entering stocks } \\
\hline & $\theta_{1}(p-v)$ & $\theta_{2}(p-v)$ & $\overline{C A R}_{\tau}$ & $\theta_{1}(p-v)$ & $\theta_{2}(p-v)$ & $\overline{C A R}_{\tau}$ & $\theta_{1}(p-v)$ & $\theta_{2}(p-v)$ & $\overline{C A R}_{\tau}$ \\
\hline-10 & $\begin{array}{l}-0,220 \\
(0,413)\end{array}$ & $\begin{array}{c}-2,828 \\
(0,002)^{*}\end{array}$ & $-0,79 \%$ & $\begin{array}{c}0,147 \\
(0,559)\end{array}$ & $\begin{array}{l}-0,539 \\
(0,295)\end{array}$ & $0,28 \%$ & $\begin{array}{l}-0,085 \\
(0,466)\end{array}$ & $\begin{array}{c}-1,414 \\
(0,079)^{* * *}\end{array}$ & $-0,18 \%$ \\
\hline-9 & $\begin{array}{l}-0,220 \\
(0,413)\end{array}$ & $\begin{array}{c}-2,828 \\
(0,002)^{*}\end{array}$ & $-1,58 \%$ & $\begin{array}{c}0,147 \\
(0,559)\end{array}$ & $\begin{array}{l}-0,539 \\
(0,295) \\
\end{array}$ & $0,57 \%$ & $\begin{array}{l}-0,085 \\
(0,466) \\
\end{array}$ & $\begin{array}{c}-1,414 \\
(0,079)^{* * *}\end{array}$ & $-0,37 \%$ \\
\hline-8 & $\begin{array}{l}-0,259 \\
(0,398)\end{array}$ & $\begin{array}{c}-2,828 \\
(0,002)^{*}\end{array}$ & $-2,56 \%$ & $\begin{array}{c}0,087 \\
(0,535)\end{array}$ & $\begin{array}{c}0,180 \\
(0,571)\end{array}$ & $0,39 \%$ & $\begin{array}{l}-0,187 \\
(0,426)\end{array}$ & $\begin{array}{l}-1,061 \\
(0,144)\end{array}$ & $-0,93 \%$ \\
\hline-7 & $\begin{array}{l}-0,346 \\
(0,365)\end{array}$ & $\begin{array}{c}-2,475 \\
(0,007)^{*}\end{array}$ & $-3,56 \%$ & $\begin{array}{c}0,027 \\
(0,511)\end{array}$ & $\begin{array}{l}-0,180 \\
(0,429)\end{array}$ & $0,13 \%$ & $\begin{array}{l}-0,424 \\
(0,336)\end{array}$ & $\begin{array}{c}-2,121 \\
(0,017)^{* *}\end{array}$ & $-2,55 \%$ \\
\hline-6 & $\begin{array}{l}-0,325 \\
(0,373) \\
\end{array}$ & $\begin{array}{c}-2,121 \\
(0,017)^{* *}\end{array}$ & $-3,90 \%$ & $\begin{array}{c}0,010 \\
(0,504)\end{array}$ & $\begin{array}{c}0,419 \\
(0,662) \\
\end{array}$ & $0,06 \%$ & $\begin{array}{l}-0,252 \\
(0,400) \\
\end{array}$ & $\begin{array}{c}-1,414 \\
(0,079)^{* * *}\end{array}$ & $-1,64 \%$ \\
\hline-5 & $\begin{array}{l}-0,343 \\
0,366)\end{array}$ & $\begin{array}{c}-2,121 \\
(0,017)^{* *}\end{array}$ & $-4,16 \%$ & $\begin{array}{c}0,024 \\
0,0209)\end{array}$ & $\begin{array}{l}-0,060 \\
(0,476)\end{array}$ & $0,14 \%$ & $\begin{array}{l}-0,213 \\
(0,416)\end{array}$ & $\begin{array}{l}-1,414 \\
(0,079)^{* * * *}\end{array}$ & $-1,44 \%$ \\
\hline-4 & $\begin{array}{l}-0,345 \\
(0,365)\end{array}$ & $\begin{array}{c}-2,121 \\
(0,017)^{* *}\end{array}$ & $-4,20 \%$ & $\begin{array}{c}0,032 \\
(0,513)\end{array}$ & $\begin{array}{l}-0,299 \\
(0,382)\end{array}$ & $0,21 \%$ & $\begin{array}{l}-0,114 \\
(0,454)\end{array}$ & $\begin{array}{l}-0,354 \\
(0,362)\end{array}$ & $-0,78 \%$ \\
\hline-3 & $\begin{array}{l}0,000) \\
-0,365 \\
(0,357)\end{array}$ & $\begin{array}{c}-2,121 \\
(0,017)^{* *}\end{array}$ & $-5,03 \%$ & $\begin{array}{c}0,001 \\
(0,500)\end{array}$ & $\begin{array}{c}0,060 \\
0,0624)\end{array}$ & $0,00 \%$ & $\begin{array}{l}-0,092 \\
(0,463)\end{array}$ & $\begin{array}{c}0,354 \\
(0,638) \\
\end{array}$ & $-0,63 \%$ \\
\hline-2 & $\begin{array}{l}-0,378 \\
(0,353)\end{array}$ & $\begin{array}{c}-1,414 \\
(0,079)^{* * *}\end{array}$ & $-5,75 \%$ & $\begin{array}{l}-0,036 \\
(0,486)\end{array}$ & $\begin{array}{l}-0,778 \\
(0,218)\end{array}$ & $-0,25 \%$ & $\begin{array}{l}-0,4050 \\
(0,480)\end{array}$ & $\begin{array}{l}-0,354 \\
(0,362)\end{array}$ & $-0,37 \%$ \\
\hline-1 & $\begin{array}{l}-0,354 \\
(0,362)\end{array}$ & $\begin{array}{c}-1,768 \\
(0,039)^{* *}\end{array}$ & $-5,31 \%$ & $\begin{array}{l}-0,052 \\
(0,479)\end{array}$ & $\begin{array}{l}-0,419 \\
(0,338)\end{array}$ & $-0,38 \%$ & $\begin{array}{l}-0,028 \\
(0,489)\end{array}$ & $\begin{array}{l}-0,707 \\
(0,240)\end{array}$ & $-0,21 \%$ \\
\hline 0 & $\begin{array}{l}-0,311 \\
(0,378)\end{array}$ & $\begin{array}{c}-2,121 \\
(0,017)^{* *}\end{array}$ & $-4,63 \%$ & $\begin{array}{l}-0,014 \\
(0,494)\end{array}$ & $\begin{array}{l}-0,180 \\
(0,429)\end{array}$ & $-0,10 \%$ & $\begin{array}{l}-0,017 \\
(0,493)\end{array}$ & $\begin{array}{l}-0,354 \\
(0,362)\end{array}$ & $-0,13 \%$ \\
\hline 1 & $\begin{array}{l}-0,327 \\
(0,372)\end{array}$ & $\begin{array}{c}-1,768 \\
(0,039)^{* *}\end{array}$ & $-4,77 \%$ & $\begin{array}{c}0,038 \\
(0,515)\end{array}$ & $\begin{array}{l}-0,060 \\
(0,476)\end{array}$ & $0,28 \%$ & $\begin{array}{c}0,019 \\
(0,508)\end{array}$ & $\begin{array}{l}-0,354 \\
(0,362)\end{array}$ & $0,15 \%$ \\
\hline 2 & $\begin{array}{l}-0,328 \\
(0,371)\end{array}$ & $\begin{array}{c}-1,768 \\
(0,039)^{* *}\end{array}$ & $-4,83 \%$ & $\begin{array}{c}0,074 \\
(0,529)\end{array}$ & $\begin{array}{c}1,377 \\
(0,916)\end{array}$ & $0,60 \%$ & $\begin{array}{c}0,070 \\
(0,528)\end{array}$ & $\begin{array}{c}0,000 \\
(0,500)\end{array}$ & $0,57 \%$ \\
\hline 3 & $\begin{array}{l}-0,290 \\
(0,386)\end{array}$ & $\begin{array}{c}-1,768 \\
(0,039)^{* *}\end{array}$ & $-4,39 \%$ & $\begin{array}{c}0,134 \\
(0,553)\end{array}$ & $\begin{array}{c}1,138 \\
(0,872)\end{array}$ & $1,13 \%$ & $\begin{array}{c}0,188 \\
(0,574)\end{array}$ & $\begin{array}{c}1,061 \\
(0,856)\end{array}$ & $1,42 \%$ \\
\hline 4 & $\begin{array}{c}-0,299 \\
(0,382)\end{array}$ & $\begin{array}{c}-1,768 \\
(0,039)^{* *}\end{array}$ & $-4,62 \%$ & $\begin{array}{c}0,101 \\
(0,540)\end{array}$ & $\begin{array}{c}1,138 \\
(0,872) \\
\end{array}$ & $0,93 \%$ & $\begin{array}{c}0,107 \\
(0,542) \\
\end{array}$ & $\begin{array}{c}0,707 \\
(0,760)\end{array}$ & $0,81 \%$ \\
\hline 5 & $\begin{array}{l}-0,341 \\
0,3671\end{array}$ & $\begin{array}{c}-1,768 \\
(0,039)^{* *}\end{array}$ & $-5,33 \%$ & $\begin{array}{c}0,087 \\
(0,535)\end{array}$ & $\begin{array}{c}1,018 \\
(0,846)\end{array}$ & $0,87 \%$ & $\begin{array}{c}0,125 \\
(0,550)\end{array}$ & $\begin{array}{c}0,354 \\
(0,638)\end{array}$ & $0,98 \%$ \\
\hline 6 & $\begin{array}{l}-0,333 \\
(0,369)\end{array}$ & $\begin{array}{c}-2,121 \\
(0,017)^{* *}\end{array}$ & $-5,10 \%$ & $\begin{array}{c}0,098 \\
(0,539)\end{array}$ & $\begin{array}{c}1,257 \\
(0,896)\end{array}$ & $1,06 \%$ & $\begin{array}{c}0,170 \\
(0,567)\end{array}$ & $\begin{array}{c}0,354 \\
(0,638)\end{array}$ & $1,43 \%$ \\
\hline 7 & $\begin{array}{l}-0,353 \\
(0,362) \\
\end{array}$ & $\begin{array}{c}-2,121 \\
(0,017)^{* *}\end{array}$ & $-5,41 \%$ & $\begin{array}{c}0,085 \\
(0,534) \\
\end{array}$ & $\begin{array}{c}1,257 \\
(0,896) \\
\end{array}$ & $0,94 \%$ & $\begin{array}{c}0,096 \\
(0,538) \\
\end{array}$ & $\begin{array}{c}0,707 \\
(0,760)\end{array}$ & $0,82 \%$ \\
\hline 8 & $\begin{array}{l}-0,260 \\
(0,397)\end{array}$ & $\begin{array}{c}-2,121 \\
(0,017)^{* *}\end{array}$ & $-4,19 \%$ & $\begin{array}{c}0,083 \\
(0,533)\end{array}$ & $\begin{array}{c}1,018 \\
(0,846)\end{array}$ & $0,91 \%$ & $\begin{array}{c}0,125 \\
(0,550)\end{array}$ & $\begin{array}{c}1,061 \\
(0,856)\end{array}$ & $1,08 \%$ \\
\hline 9 & $\begin{array}{l}-0,241 \\
(0,405)\end{array}$ & $\begin{array}{c}-1,414 \\
(0,079)^{* * *}\end{array}$ & $-4,01 \%$ & $\begin{array}{c}0,072 \\
(0,529)\end{array}$ & $\begin{array}{c}1,736 \\
(0,959)\end{array}$ & $0,80 \%$ & $\begin{array}{c}0,180 \\
(0,572)\end{array}$ & $\begin{array}{c}0,707 \\
(0,760)\end{array}$ & $1,52 \%$ \\
\hline 10 & $\begin{array}{l}-0,335 \\
(0,369)\end{array}$ & $\begin{array}{c}-1,768 \\
(0,039)^{* *}\end{array}$ & $-5,38 \%$ & $\begin{array}{c}0,085 \\
(0,534)\end{array}$ & $\begin{array}{c}1,616 \\
(0,947)\end{array}$ & $0,96 \%$ & $\begin{array}{c}0,192 \\
(0,576)\end{array}$ & $\begin{array}{c}1,061 \\
(0,856)\end{array}$ & $1,77 \%$ \\
\hline
\end{tabular}

Note: ${ }^{*}{ }^{* *}$ and ${ }^{* * *}$ denote statistical significance on $1 \%, 5 \%$ and $10 \%$.

Source: author's calculation. 

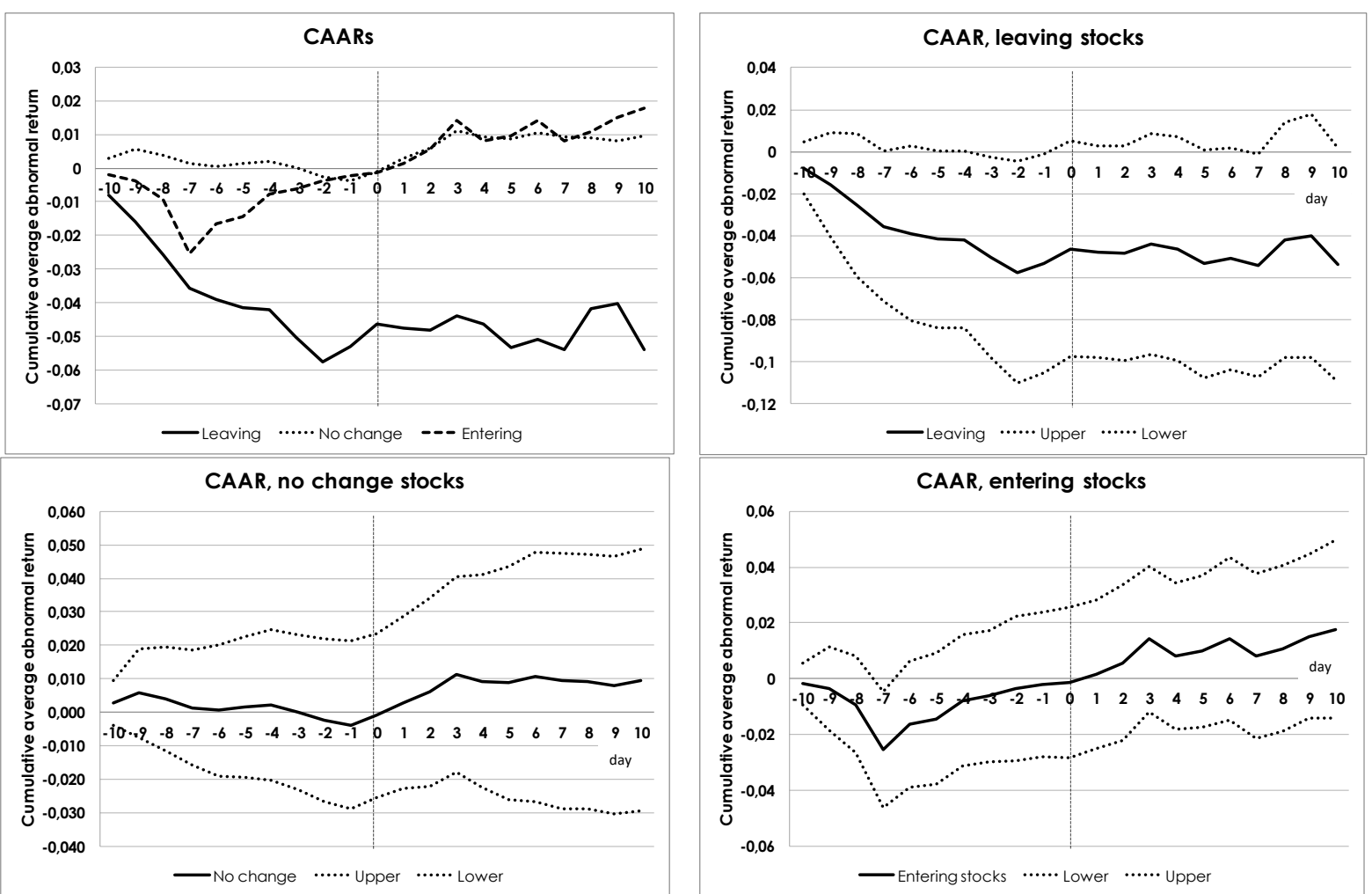

Figures 1-4 Cumulated abnormal returns for the subsets of stocks on ZSE

Note: Lower and Upper denote lower and upper bands of interval estimation at $95 \%$ confidence level.

Source: author's calculation.

Graphical representation of cumulated abnormal returns is shown in Figures 1-4. Figure 1 compares $\overline{C A R}_{\tau}$ for every subsample of stocks in the observed period for all of the event windows. A significant negative cumulative abnormal return is prominent for the stocks leaving the market index, whilst positive returns can be observed for the other two groups of stocks after the event day. However, these returns were not statistically significant. Nevertheless, the asymmetric effects of inclusion or exclusion are quite visible. By looking at the no change group of stocks graph, the abnormal return path follows the assumption in $\mathrm{EMH}$. There is an instantaneous mild shift of the value of abnormal return, with no constant increase or decrease. Additionally, a t-test was performed in order to compare the rate of return change for stocks leaving and entering the market index. In that way, the second research hypothesis could have been tested. The empirical test value is equal to -2.17 with the corresponding two-tail test $p$-value of 0.04 , which rejects the null hypothesis of equal rate of return change. In other words, the second research hypothesis was confirmed as well, there exist asymmetries in stock return behaviour around the announcement dates.

\section{Conclusion}

The debate on stock index entrance and exit of individual stocks and the effects on stock prices has been ongoing for quite some time now. The event study methodology was found useful to provide answers regarding stock demand curve slope, both in the short and long run. By assessing the information on the aforementioned effects, (potential) investors can get insights into the general picture of the stock demand curve and the potentials of substituting their stocks in portfolios. Moreover, based upon the results, profitable trading strategies could be constructed in order to exploit if some 
anomalies in return series do exist. This initial research on stock market index composition changes effects on stock returns in Croatia focused on three basic subgroups of stocks. The most common group observed in the literature is the entering group, with the majority of theoretical approaches focusing on them. The results for the observed period on ZSE show that there exists a positive shift of abnormal returns for this group of stocks after the announcement day, however, it was not statistically significant. Negative abnormal returns for this first group before the announcement day could be consistent with the liquidity hypothesis. Stocks leaving the market index exhibit significant negative returns. This result is consistent with previous studies and with the information hypothesis. In that way, there exist to some extent possibilities to obtain trading profits in the short run due to the behaviour of cumulative abnormal returns for each subgroup of stocks. The results are important for all current and potential investors who aim to optimize values of their portfolios on the Zagreb Stock Exchange. Moreover, the results are important for companies to predict how investors perceive those companies when announcements on including or excluding from the market index occur. Thus, when a company predicts inclusion to of exclusion from the index, it should signal different signals to (potential) investors, in order to obtain optimal results regarding stock price increase/decrease.

Some of the pitfalls of the study were as follows. Effects of index restructuring have been observed only in stock returns. Liquidity and volatility can also be observed in order to obtain information on their changes relative to restructuring announcements. However, there are many problems with measuring the liquidity of stocks on a market such as the Croatian (please see Minović (2012) and Vidović (2013) for more information). Future research will be extended by including more revisions of the stock market index, so a relevant number of extraordinary revisions can be separated as a special type of subsample in order to compare the results with the regular revisions. Moreover, the date when the index composition changes will be observed as the announcement date as well. Although the researched hypotheses in this study regard stock return, future work can observe the effects on return volatility as well. Since the purpose of this study was to summarize the main theory results and obtain a first insight whether any effects exist in returns on ZSE, there remain many questions to explore in future research as well. Thus, future work should explore sector effects of the topic explored here, the longer time spans can be observed as well, due to looking at longterm demand. Moreover, the volatility series and volatility reactions have to be taken into consideration as well, due to risks being important to investors as well.

\section{References}

1. Bartholdy, J., Olson, D., Peare, P. (2007). Conducting event studies on small stock exchange. The European Journal of Finance, Vol. 13, No. 3, pp. 227-252.

2. Bechman, K. L. (2004). Price and Volume Effects Associated with Changes in the Danish Blve-Chip Index: The KFX Index. Multinational Finance Journal, Vol. 8, No. 1/2, pp. 3-34.

3. Blume, M. E., Edelen, R. M. (2002). On Replicating the S\&P 500 Index. Available at https://rodneywhitecenter.wharton.upenn.edu/wp-content/uploads/2014/04/0208.pdf [01 June 2018].

4. Chen, H., Noronha, G., Singal, V. (2004). The Price Response to S\&P 500 Index Additions and Deletions: Evidence of Asymmetry and a New Explanation. The Journal of Finance, Vol. 59, No. 4, pp. 1901-1930.

5. Corrado, C. J. (2010). Event studies: A Methodology Review. Available at https://papers.ssrn.com/sol3/papers.cfm?abstract_id=1441581 [20 May 2018]

6. Dhillon, U., Johnson, H. (1991). Changes in the Standard and Poor's 500 list. Journal of Business, Vol. 64, No. 1, pp. 75-85. 
7. Duque, J., Madeira, G. (2004). Effects associated with index composition changes: evidence from the Euronext Lisbon stock exchange, Instituto Superior de Economia e Gestão - Departamento de Gestão, Working papers series, No. 5, pp. 1-35.

8. Elliott, W. B., Ness, B. F., Walker, M. D., Wan, R. S. (2006). What Drives the S\&P 500 Inclusion Effect? An Analytical Survey. Financial Management, Vol. 35, No. 4, pp. $31-48$.

9. Erwin, G. R., Miller, J. M. (1998). The liquidity effects associated with the addition of a stock to the S\&P 500 index: evidence from bid/ask spreads. Financial Review, Vol. 33, No. 1, pp. 131-146.

10. Fama, E. (1965). The Behaviour of Stock Market Prices. Journal of Business, Vol. 38, pp. 34105.

11. Fama. E. (1970). Efficient Capital Markets: A Review of Theory and Empirical Work. Journal of Finance, Vol. 25, No. 2, pp. 383-417.

12. Gregoriou, A. (2011). The Liquidity Effects of Revisions to the CAC40 Stock Index. Applied Financial Economics, Vol. 21, No. 5, pp. 333-341.

13. Gregoriou, A., loannidis, C. (2006). Information costs and liquidity effects from changes in the FTSE 100 list. European Journal of Finance, Vol. 12, No. 4, pp. 347-360.

14. Harris, L, Gurel, E. (1986). Price and Volume Effects Associated with Changes in the S\&P 500 List: New Evidence for the Existence of Price Pressures. The Journal of Finance, Vol. 41, No. 4, pp. 815-829.

15. Hegde, S. P., McDermott, J. B. (2003). The liquidity effects of revisions to the S\&P 500 index: an empirical analysis. Journal of Financial Markets, Vol. 6, No. 3, pp. 413-459.

16. Jain, P. (1987). The effect on stock price from inclusion in or exclusion from the S\&P 500. Financial Analysts Journal, Vol. 43, No. 1, pp. 58-65.

17. Kaul, A., Mehrotra, V., Morck, R. (2000). Demand curves for stock do slope down: New evidence from an index weights adjustment. Journal of Finance, Vol. 55, No. 2, pp. 893-912.

18. Kothari, S. P., Warner, J. B. (2007). Econometrics of Event Studies. In: Handbook of Corporate finance - Empirical Corporate Finance, Vol. 1, Espen Eckbo, B. (Ed.). Netherlands: Elsevier.

19. Kraus, A., Stoll, H. (1972). Price Impacts of Block Trading on the New York Stock Exchange. Journal of Finance, Vol. 27, No. 3, pp. 569-588.

20. Lynch, A. W., Mendenhall, R. R. (1997). New Evidence on Stock Price Effects Associated with Changes in the S\&P500 Index. Journal of Business, Vol. 70, No. 3, pp. 351-383.

21. MacKinlay A. C. (1997). Event Studies in Economics and Finance. Journal of Economic Literature, Vol. 35, No. 1, pp. 13-39.

22. Mase, B. (2007). The impact of changes in the FTSE 100 index. The Financial Review, Vol. 42, No. 3, pp. 461-484.

23. Merton, R. C. (1987). A simple model of capital market equilibrium with incomplete information. Journal of Finance, Vol. 42, No. 3, pp. 483-510.

24. Miletić, M. (2011). Stock price reaction to dividend announcement in Croatia. Economic research - Ekonomska istraživanja, Vol. 24, No. 3, pp. 147-156.

25. Minović, J. Z. (2012). Liquidity of the Croatian Stock Market: An Empirical Analysis. Economic Research - Ekonomska istraživanja, Vol. 25, No. 3, pp. 776-801.

26. Oberndorfer, U., Schmidt, P., Wagner, M., Ziegler, A. (2013). Does the Stock Market Value the Inclusion in a Sustainability Stock Index? An Event Study Analysis for German Firms. Journal of Environmental Economics and Management, Vol. 66, No. 3, pp. 497-509.

27. Scholes, M. (1972). The Market for Securities: Substitution versus Price Pressure and the Effects of Information on Share Prices. The Journal of Business, Vol. 45, No. 2, pp. 179-21 1.

28. Shleifer, A. (1986). Do demand curves for stocks slope down?. The Journal of Finance, Vol. 41, No. 3, pp. 579-590.

29. Škrinjarić, T., Orlović. Z. (2019). Effects of economic and political events on stock returns: event study of Agrokor case in Croatia. Croatian Economic Survey. Forthcoming.

30. Vespro, C. (2006). Stock Price and Volume Effects Associated with Compositional Changes in European Stock Indices. European Financial Management Association, Vol. 12, No. 1, pp. 103-127.

31. Vidović, J. (2013). Investigation of stock illiquidity on Central and South East European markets in naive porffolio framework. Ekonomska misao i praksa, Vol. 8, No. 2, pp. 537-550. 
32. Wurgler, J., Zhuravskaya, E. (2002). Does Arbitrage Flatten Demand Curves for Stocks?. The Journal of Business, Vol. 75, No. 4, pp. 583-608.

33. Zagreb Stock Exchange (2018). Zagreb Stock Exchange main web page. Available at http://www.zse.hr [01 June 2018].

\section{About the author}

Tihana Škrinjarić, PhD, is employed as a postdoctoral researcher at the Department of Mathematics at the Faculty of Economics and Business of the University of Zagreb. Her research areas are risk management, econometrics and financial economics, with special focus on regime switching methodology and portfolio management. She has published more than 60 publications in the abovementioned research areas; she has participated at nine international conferences on econometrics and operational research. Tihana has been a member of the Croatian Operational Research Society and the Croatian Statistical Association. She may be contacted at tskrinjar@net.efzg.hr. 